\title{
MODEL LAJU PENGERINGAN SPAGHETTI JAGUNG MENGGUNAKAN TRAY DRIER
}

\author{
[Drying Model of Corn Spaghetti using Tray Drier]
}

\author{
Tjahja Muhandri ${ }^{1,2) \star}$, Gina Nur Rahmasari ${ }^{1}$, Subarna, ${ }^{1,2)}$, dan Purwiyatno Hariyadi ${ }^{1,2)}$ \\ ${ }^{1)}$ Departemen Ilmu dan Teknologi Pangan, Fakultas Teknologi Pertanian, Institut Pertanian Bogor, Bogor \\ 2) SEAFAST Center, Institut Pertanian Bogor, Bogor
}

Diterima 01 Mei 2015 / Disetujui 25 November 2015

\begin{abstract}
Drying is the most crucial process that determines the final quality of pasta products. Drying at high temperature has been widely used; however, it may cause texture damage in the form of cracking in the product. Drying model can be used in drying process control to prevent such kind of damage and also to design an optimum drying condition. The objective of this research is to determine the drying model of corn spaghetti using a tray drier. In this study, drying was performed at three levels of air velocity (1.29; 0.90; and $0.49 \mathrm{~m} / \mathrm{s})$, three levels of instrument temperature setting (6, 8, and 10), and two setting of drying position (vertical and horizontal to the airflow). Results indicated that drying temperature was the most influencing parameter in corn spaghetti drying. It also could be concluded that the drying rate of corn spaghetti could be well represented by thin layer drying equation (Page model).
\end{abstract}

Keywords: corn spaghetti, drying model, tray drier

\begin{abstract}
ABSTRAK
Pengeringan merupakan proses paling krusial yang menentukan kualitas akhir produk pasta. Dalam hal ini, pengeringan dengan suhu tinggi telah banyak digunakan. Namun pengeringan pada suhu tinggi memungkinkan terjadinya kerusakan pada tekstur berupa cracking (retak) pada produk. Model laju pengeringan dapat digunakan dalam pengendalian proses pengeringan untuk mencegah kerusakan ini dan merancang kondisi proses yang optimum. Tujuan penelitian ini adalah untuk menentukan model laju pengeringan spageti jagung dengan menggunakan tray drier. Pada penelitian ini pengeringan dilakukan pada tiga level kecepatan udara $(1,29 ; 0,90 ; 0,49 \mathrm{~m} / \mathrm{s})$, tiga level pengaturan suhu alat pengering (level suhu 6,8 , dan 10), dan dua pengaturan posisi pengeringan (vertikal dan horisontal terhadap aliran udara pengering). Hasil menunjukkan bahwa parameter yang paling mempengaruhi laju pengeringan spageti jagung adalah suhu udara pengering. Selain itu, dapat disimpulkan bahwa laju pengeringan spageti jagung dapat direpresentasikan dengan baik dengan persamaan lapis tipis (Page model).
\end{abstract}

Kata kunci: model laju pengeringan, spaghetti jagung, tray drier

\section{PENDAHULUAN}

Spaghetti adalah jenis pasta yang paling populer. FDA menggolongkan spaghetti kedalam produk makaroni dan mi. Menurut standar identitas FDA (21CFR139.110), spaghetti adalah produk pasta yang memiliki bentuk seperti tali dengan ukuran diameter antara 0,06-0,11 inci (FDA, 2013). Spaghetti jagung adalah produk pangan berbasis tepung jagung yang diolah dengan teknologi menggunakan ekstrusi dan memiliki bentuk dan ukuran yang memenuhi definisi spaghetti dari standar identitas FDA.
Pengeringan merupakan proses paling krusial yang akan menentukan kualitas akhir produk pasta. Pengeringan dengan suhu tinggi telah banyak diterapkan di industri pasta untuk menggantikan pengeringan konvensional. Profil suhu tinggi yang digunakan berkisar antara $60-90^{\circ} \mathrm{C}$ (Villeneuve dan Géllinas, 2007). Proses pengeringan pada suhu tinggi memungkinkan terjadinya kerusakan berupa cracking (retak) pada produk spaghetti. Oleh karena itu, pengendalian terhadap tahap pengeringan berdasarkan pada model prediksi dapat digunakan untuk merancang kondisi proses yang optimal (Migliori et al., 2005).

*Penulis Korespondensi:

E-mail: cahyomuhandri@yahoo.com 
Beberapa persamaan pengeringan yang terdapat di literatur telah berhasil menjelaskan pengeringan beberapa produk $\mathrm{mi}$ dan pasta. Pamungkas et al. (2008) meneliti perubahan konstanta laju pengeringan untuk produk pasta puffing menggunakan model Lewis yang analog dengan persamaan pendinginan Newton. Kaushal dan Sharma (2013) menyatakan model matematik Verma dapat menggambarkan perilaku pengeringan mi yang terbuat dari tepung talas, beras, dan pigeonpea. Kongkiattisak dan Songsermpong (2012) juga meneliti model matematik Two-Term sebagai model yang paling tepat merepresentasi pengeringan mi beras.

Secara umum terdapat tiga jenis model pengeringan lapis tipis yaitu, model teoritis, semiteoritis, dan empiris. Pendekatan teoritis berkaitan dengan persamaan difusi maupun persamaan perpindahan panas dan massa secara simultan. Model empiris mengabaikan dasar-dasar teori dan menyajikan hubungan langsung antara kadar air rata-rata dengan waktu pengeringan melalui analisis regresi. Model semi-teoritis adalah alternatif antara pendekatan teoritis dan empiris, diturunkan dari penyederhanaan hukum kedua Fick mengenai difusi, atau modifikasi dari model yang disederhanakan, seperti model Henderson-Pabis, model Page, model Modified Page, dan lainnya (Kaushal dan Sharma, 2013).

Pengeringan lapis tipis merupakan pengeringan satu lapisan dari partikel atau potongan bahan. Karena strukturnya yang tipis, distribusi suhu dapat diasumsikan seragam dan pengeringan lapis tipis cocok untuk model parameter lumped. Persamaan lapis tipis dapat berupa model persamaan teoritis, semiteoritis, dan empiris. Model teoritis hanya mempertimbangkan resistansi internal bahan terhadap transfer uap air. Sementara model lainnya hanya mempertimbangkan resistansi eksternal terhadap transfer uap air antara produk dan udara (Erbay dan Icier, 2010).

Model teoritis menjelaskan perilaku pengeringan produk dengan jelas dan dapat digunakan untuk semua kondisi proses, yang menyertakan banyak asumsi yang dapat menyebabkan error. Model teoritis yang paling banyak digunakan diturunkan dari hukum kedua Fick mengenai difusi. Demikian pula, model semiteoritis secara umum diturunkan dari hukum kedua Fick tentang difusi, dan modifikasi dari bentuk sederhananya (model semiteoritis lain diturunkan dari analog hukum pendinginan Newton). Model semiteoritis lebih mudah dan membutuhkan lebih sedikit asumsi karena menggunakan data hasil percobaan. Model empiris juga hampir sama dengan model semiteoritis. Model ini sangat berrgantung pada kondisi percobaan dan memberikan informasi yang terbatas mengenai perilaku pengeringan (Erbay dan Icier, 2010).
Model semiteoritis dapat diklasifikasikan berdasarkan persamaan asalnya yaitu hukum kedua Fick tentang difusi dan hukum pendinginan Newton. Model yang diturunkan dari hukum kedua Fick mengenai difusi dapat diklasifikasikan kembali menjadi model Henderson-Pabis (Single term), model Logarithmic, model Midilli, model Two-term, model Two-term exponential, dan modifikasi dari modelmodel tersebut. Model yang diturunkan berdasarkan analogi dari hukum pendinginan Newton adalah model Lewis, dan model Page beserta modifikasinya (Erbay dan Icier, 2010).

Belum ada literatur yang menyebutkan pemodelan kinetika pengeringan untuk $\mathrm{mi}$ atau pasta berbahan dasar tepung jagung. Penelitian ini bertujuan untuk mendapatkan persamaan model laju pengeringan yang dapat merepresentasikan dengan baik perilaku pengeringan spageti jagung pada berbagai kondisi suhu dan kecepatan udara pengering.

\section{BAHAN DAN METODE}

\section{Bahan}

Bahan utama yang digunakan dalam penelitian ini adalah tepung jagung varietas P21 (100 mesh) yang diperoleh dari Satuan Usaha Akademik (SUA) Departemen ITP FATETA-IPB.

\section{Pembuatan spageti jagung}

Spageti jagung dibuat dengan teknologi yang dikembangkan oleh Subarna et al. (2012) dengan modifikasi. Tepung jagung (100\%) dicampur dengan GMS $(0,8 \%)$, aquades $(70 \%)$, dan garam dapur (2\%). Bahan-bahan dicampur menggunakan hand mixer (Philips, Indonesia) selama 5 menit. Adonan dicetak menggunakan ekstruder pemasak-pencetak (Labtech Engineering Co. Ltd., Thailand) dengan spesifikasi single screw, increasing root diameter, constant pitch, rasio screw L/D 30, speed 0-30 rpm, diameter barrel konstan 2,52 cm, permukaan dalam barrel halus, breaker plate dengan 21 lubang dengan diameter masing-masing 2,5 $\mathrm{mm}$, motor penggerak screw dengan daya $4 \mathrm{~kW}$ dan empat buah heater, dengan pengaturan suhu $95^{\circ} \mathrm{C}$ dan kecepatan ulir $130 \mathrm{rpm}$. Die yang digunakan berbentuk elips dengan diameter pendek $1 \mathrm{~mm}$ dan diameter panjang $1,5 \mathrm{~mm}$.

\section{Pengeringan spageti jagung}

Pengeringan dimulai 30 menit setelah spageti jagung keluar dari ekstruder yang dilakukan untuk preparasi sampel. Spageti jagung dipotong, ditata di kawatkasa sesuai perlakuan posisi, dan ditimbang. Pengeringan dilakukan menggunakan tray drier (Armfield Horizontal Model, England) dengan variabel pengaturan suhu pada nomor 6,8 , dan 10 serta pengaturan kecepatan udara pada nomor 4,7 , 
dan 10. Kecepatan udara di lokasi peletakan produk, diukur menggunakan anemometer (Ogawa Seiki, Jepang). Spageti jagung dikeringkan dengan posisi vertikal dan horizontal terhadap aliran udara pengering. Selama proses pengeringan, setiap 10 menit hingga penurunan berat yang menghasilkan kadar air $\pm 10 \%$. Pengering hingga berat sampel tidak lagi berubah Seluruh sampel kemudian diukur kadar airnya. Seluruh percobaan pengeringan dilakukan dengan dua kali pengulangan perlakuan.

Setiap proses pengeringan dilakukan, suhu aktual udara pengering diukur menggunakan termometer. Sementara kecepatan udara hanya diukur sekali saja di awal penelitian. Suhu yang dicantumkan pada Tabel 1 merupakan suhu yang terbaca di termometer setiap melakukan pengeringan. Suhu aktual dari satu level pengaturan suhu yang sama berbeda untuk setiap level kecepatan udara. Level kecepatan udara yang tinggi menyebabkan udara bergerak lebih cepat dan hanya memiliki waktu kontak yang singkat di heater. Sementara untuk level kecepatan udara yang lebih rendah, udara lebih lambat bergerak dan terkena ekspos panas lebih lama ketika melewati heater sehingga memungkinkan suhu untuk naik lebih tinggi lagi.

Tabel 1. Suhu dan kecepatan udara pengering

\begin{tabular}{ccccc}
$\begin{array}{c}\text { Kecepatan } \\
\begin{array}{c}\text { Udara } \\
\text { di Alat }\end{array}\end{array}$ & $\begin{array}{c}\text { Kece- } \\
\text { patan } \\
\text { Udara }\end{array}$ & $\begin{array}{c}\text { Pengaturan } \\
\text { Suhu } \\
\text { di Alat }\end{array}$ & $\begin{array}{c}\text { Suhu } \\
\left({ }^{\circ} \mathrm{C}\right)\end{array}$ & $\begin{array}{c}\text { Rata } \\
\text {-rata } \\
\text { Suhu } \\
\left({ }^{\circ} \mathrm{C}\right)\end{array}$ \\
\hline 10 & 1,29 & 10 & $58-64$ & 61 \\
& & 8 & $50-54$ & 52 \\
7 & 0,9 & 10 & $38-44$ & 41 \\
& & 8 & $55-62$ & 58 \\
4 & 0,49 & 10 & $84-53$ & 48 \\
& & 8 & $70-81$ & 75 \\
& & 6 & $50-60$ & 55 \\
\hline
\end{tabular}

\section{Analisis kadar air (BSN, 1992)}

Analisis kadar air dilakukan dengan metode oven. Cawan kosong dan tutupnya dikeringkan dalam oven selama 15 menit. Setelah itu, cawan didinginkan dalam desikator. Cawan kering yang telah didinginkan ditimbang (A) kemudian sebanyak 1-2 gram sampel spageti jagung kering (B) dimasukkan ke dalam cawan tersebut. Cawan yang berisi sampel dikeringkan kembali di dalam oven pada suhu $105^{\circ} \mathrm{C} \pm 1^{\circ} \mathrm{C}$ selama 5 jam. Setelah itu, cawan didinginkan dalam desikator dan ditimbang (C) hingga diperoleh berat konstan. Perhitungan kadar air :

$$
\begin{aligned}
& \% \text { Kadar air }(\mathrm{bb})=\frac{\mathrm{B}-(\mathrm{C}-\mathrm{A})}{\mathrm{B}} \times 100 \% \\
& \% \text { Kadar air }(\mathrm{bk})=\frac{\mathrm{B}-(\mathrm{C}-\mathrm{A})}{(\mathrm{C}-\mathrm{A})} \times 100 \%
\end{aligned}
$$

\section{Pembuatan persamaan model laju pengeringan}

Data kadar air sampel dan kadar air kesetimbangan digunakan untuk membuat persamaan model laju pengeringan. Kadar air yang digunakan adalah kadar air basis kering. Persamaan laju pengeringan dibuat mengikuti model pengeringan menurut Lewis dan model Page.

\section{Model Lewis}

Model Lewis mengusulkan bahwa selama pengeringan bahan higroskopis, perubahan kadar air bahan pada periode laju menurun adalah proporsional terhadap perbedaan antara kadar air dan kadar air kesetimbangan. Konsep ini mengasumsikan bahwa bahan cukup tipis atau kecepatan udara sangat tinggi dan kondisi udara pengering seperti suhu dan $\mathrm{RH}$ konstan.

$\frac{\mathrm{dM}}{\mathrm{dt}}=-\mathrm{k}\left(\mathrm{M}-\mathrm{M}_{\mathrm{e}}\right)$

Nilai $k$ adalah konstanta laju pengeringan yang merupakan kombinasi dari sifat-sifat perpindahan pada pengeringan seperti difusifitas efektif, kadar air, konduktivitas termal, dan koefisien massa (Erbay dan Icier, 2010).

Persamaan tersebut merupakan persamaan diferensial karena menyatakan hubungan antara fungsi dan turunannya. Dengan memisahkan dan meletakan variabel yang memiliki kadar air ke bagian kiri persamaan dan variabel yang memiliki waktu ke bagian kanan, kemudian diintegralkan, maka persamaan menjadi:

$$
\int \frac{d M}{\left(M-M_{e}\right)}=\int-k d t \quad \ln \frac{M_{t}-M_{e}}{M_{i}-M_{e}}=-k t .
$$

atau

$M R=\frac{M_{t}-M_{e}}{M_{i}-M_{e}}=\exp (-k t)$

Dengan $\mathrm{M}_{\mathrm{t}}$ adalah kadar air (basis kering) pada berbagai waktu $\mathrm{t}$; $\mathrm{M}_{\mathrm{e}}$ adalah kadar air kesetimbangan; $M_{i}$ adalah kadar air awal dari bahan; dan $k$ adalah konstanta pengeringan. $\frac{M_{t}-M_{e}}{M_{i}-M_{e}}$ disebut juga sebagai moisture content ratio atau MR.

\section{Model Page}

Model Page memodifikasi model Lewis untuk mendapat model yang lebih akurat dengan menambahkan konstanta $\mathrm{n}$ dan digunakan pada model matematika pengeringan jagung kupas. Sejak itu 
persamaan Page telah banyak digunakan untuk karakterisasi pengeringan lapis tipis serealia, oilseeds, ear corn, dan cengkeh (Jayas et al., 1991).

$M R=\frac{M_{t}-M_{e}}{M_{i}-M_{e}}=\exp \left(-k t^{n}\right)$

Persamaan (4) dapat dibuat linear dengan menambahkan logaritma natural pada kedua sisi persamaan.

$\ln (-\ln M R)=\ln (k)+n(\ln t)$

\section{HASIL DAN PEMBAHASAN}

\section{Pengaruh kondisi pengeringan terhadap laju pengeringan}

Pengaruh kondisi pengeringan terhadap karakteristik pengeringan spageti jagung ditunjukkan dalam bentuk kurva pengeringan (Gambar 1). Penurunan kadar air terjadi dengan cepat namun kemudian melambat seiring bertambahnya waktu pengeringan. Pada suhu yang tinggi penurunan kadar air terjadi sangat cepat dan efektif. Seperti pada suhu $92^{\circ} \mathrm{C}$ dimana hanya dibutuhkan waktu 50 menit untuk menurunkan kadar air hingga $10 \%$. Sementara penurunan kadar air yang paling lambat terjadi pada suhu $41^{\circ} \mathrm{C}$. Penurunan kadar air terjadi berimpit pada perlakuan suhu $73^{\circ} \mathrm{C}$ dan $75^{\circ} \mathrm{C}$ posisi vertikal menunjukkan laju pengeringan yang tidak terlalu berbeda antara dua level suhu yang berdekatan. Hal ini menunjukkan bahwa suhu udara pengering mempengaruhi kecepatan pengeringan spageti jagung. Suhu udara pengering dan kadar air awal bahan adalah faktor utama yang mem- pengaruhi laju perpindahan panas dan uap air (Jayas et al., 1991).

Kurva pengeringan antar perlakuan suhu dan kecepatan udara pada posisi horizontal tampak lebih menyebar dibanding kurva pengeringan pada posisi vertikal yang terlihat lebih menumpuk pada kisaran suhu $48-61^{\circ} \mathrm{C}$. Secara umum, posisi pengeringan vertikal memperlihatkan waktu pengeringan yang lebih lama untuk mencapai kadar air akhir 10\%. Hal ini dapat disebabkan oleh terjadinya case hardening karena laju pengeringan yang terlalu cepat di periode awal pengeringan. Penguapan yang cepat di permukaan bahan dapat menyebabkan pembentukkan lapisan keras permukaan yang menghambat pemindahan uap air dari dalam bahan sehingga mengurangi laju pengeringan (Thao dan Noomhorm, 2011). Kecepatan udara pengering tidak memiliki pengaruh langsung terhadap penurunan kadar air spageti jagung. Kecepatan udara pengering lebih berperan dalam pengontrolan suhu udara pengering. Lebih jauh disebutkan bahwa kecepatan udara selama pengeringan lapis tipis bijibijian memiliki sedikit pengaruh terhadap laju pengeringan (Jayas et al., 1991).

Kurva laju pengeringan spageti jagung dapat dilihat pada Gambar 2. Laju pengeringan spageti jagung terjadi sangat cepat sejak awal pengeringan dimulai dan langsung menurunkan kadar air dalam jumlah yang besar. Namun pada kadar air tertentu terjadi pembelokan kurva menjadi landai yang menunjukkan penurunan laju pengeringan. Seiring berjalannya proses pengeringan, laju pengeringan menurun karena air yang diuapkan di permukaan bahan semakin sedikit dan mengandalkan perpindahan air dari dalam bahan ke permukaan (Thao dan Noomhorm, 2011).
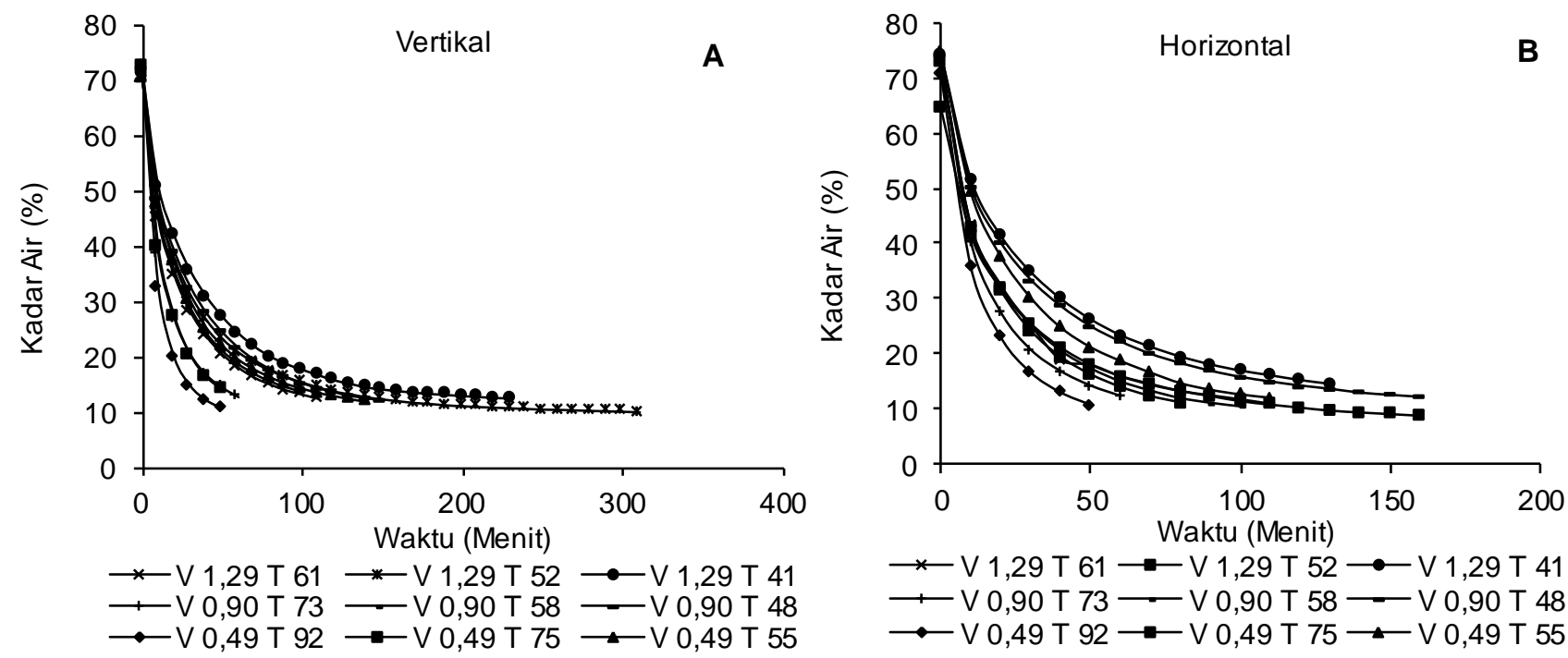

Gambar 1. Kurva pengeringan (kadar air terhadap waktu) spageti jagung pada posisi produk vertikal (A) dan horizontal (B) terhadap arah udara pengering. Pengeringan dilakukan pada berbagai kecepatan dan suhu udara pengering 
Bentuk kurva yang langsung menurun curam menunjukkan tidak terdapatnya periode laju pengeringan konstan pada pengeringan spageti jagung. Sehingga pengeringan spageti jagung terjadi pada periode laju pengeringan menurun karena kandungan air didalamnya yang terikat kuat pada struktur pati. Lebih lanjut ketiadaan laju pengeringan konstan juga mengindikasikan mekanisme fisik dominan yang mempengaruhi perpindahan air pada spageti jagung adalah difusi molekuler (Kongkiattisak dan Songsermpong, 2012).

\section{Model persamaan laju pengeringan spageti jagung}

Persamaan lapis tipis yang digunakan dalam penentuan model matematika pengeringan spageti jagung adalah persamaan turunan dari hukum pendinginan Newton yaitu model Lewis dan model Page. Model semiteoritis lebih mudah digunakan dan membutuhkan lebih sedikit asumsi karena menggunakan data hasil percobaan (Erbay dan Icier, 2010). Dalam memilih model yang sesuai untuk menjelaskan proses pengeringan pada berbagai kondisi pengeringan, model yang valid secara statistik ditentukan dengan koefisien determinasi $\left(r^{2}\right)$. Nilai $r^{2}$ yang lebih tinggi adalah indikator yang digunakan dalam memilih model yang paling sesuai (Kongkiattisak dan Songsermpong, 2012; Kaushal dan Sharma, 2013).

Tabel 2 menunjukkan model persamaan dan koefisien korelasi dari setiap perlakuan kondisi pengeringan yang diperoleh berdasarkan persamaan model Lewis dan model Page. Bentuk persamaan model Lewis adalah $\mathrm{MR}=\exp (-\mathrm{kt})$, dan untuk model Page adalah $\mathrm{MR}=\exp \left(-\mathrm{kt}^{\mathrm{n}}\right)$. Penggunaan model Lewis menghasilkan koefisien korelasi yang sangat beragam antar perlakuan. Sementara untuk model
Page hampir seluruh perlakuan percobaan memiliki nilai koefisien korelasi diatas 0,99 . Hal ini menunjukkan bahwa model Page dapat menggambarkan dengan baik perilaku pengeringan spageti jagung berdasarkan data percobaan. Dari persamaan laju pengeringan pada Tabel 2 juga dapat dilihat nilai konstanta laju pengeringan (k). Nilai k yang semakin besar dengan meningkatnya suhu pengeringan menunjukkan semakin cepatnya laju pengeringan terjadi. Hasil serupa diperoleh Simal et al. (2005), parameter $\mathrm{k}$ dari model Page meningkat dengan meningkatnya suhu udara pengeringan kiwi untuk seluruh rentang suhu yang dilakukan pada percobaan. Semakin tinggi suhu udara pengering maka nilai $\mathrm{k}$ akan semakin besar karena panas yang diberikan semakin tinggi dan penguapan air terjadi semakin cepat (Rahayoe et al., 2008). Page tidak memberikan alasan apapun terkait parameter $n$ selain penggunaannya dapat membuat persamaan yang lebih tepat menggambarkan data percobaan (Jayas et al., 1991).

Persamaan yang dapat menggambarkan pengaruh masing-masing perlakuan terhadap laju pengeringan dapat dilihat pada Gambar 3, 4, dan 5 melalui kurva hubungan regresi linear dari model persamaan Page. Laju pengeringan spageti jagung terjadi lebih cepat pada kecepatan udara pengering yang lebih rendah dengan pengaturan suhu yang sama karena suhu aktual di udara pengering yang lebih tinggi (Gambar 3). Pada kecepatan udara yang sama dan pengaturan suhu yang berbeda, pengaruh suhu terhadap laju pengeringan spageti jagung terlihat sangat jelas pada kurva pengeringan model Page (Gambar 4). Pengeringan pada suhu tinggi menyebabkan laju pengeringan yang lebih tinggi karena kapasitas udara pengering menampung air menjadi lebih besar (Subarna dan Muhandri, 2013).
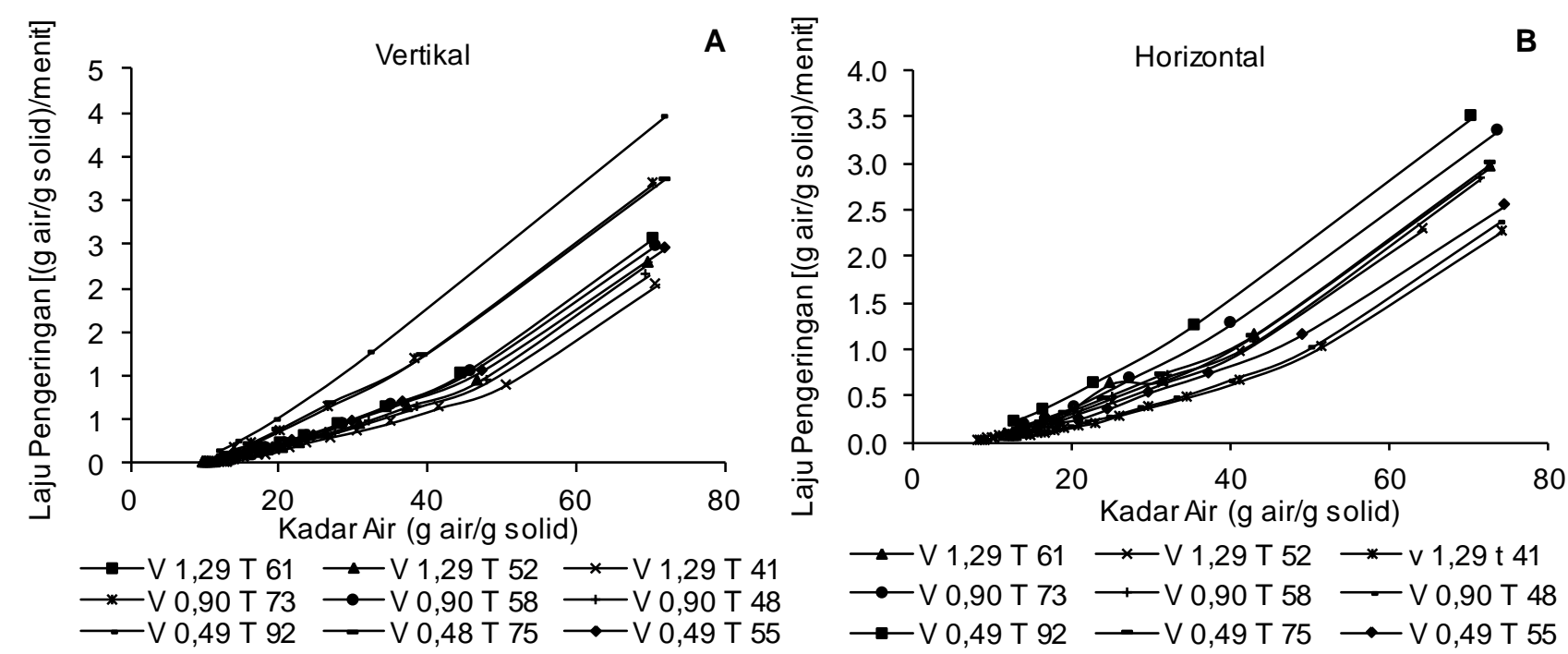

Gambar 2. Kurva laju pengeringan spageti jagung pada posisi produk vertikal (A) dan horizontal (B) terhadap arah udara pengering. Pengeringan dilakukan pada berbagai kecepatan dan suhu udara pengering 
Tabel 2. Model persamaan laju pengeringan dan koefisien korelasi berdasarkan model Lewis dan model

\begin{tabular}{|c|c|c|c|c|c|c|c|}
\hline \multirow{2}{*}{$\begin{array}{l}\text { Kec. Udara } \\
\quad(\mathrm{m} / \mathrm{s})\end{array}$} & \multirow{2}{*}{$\begin{array}{l}\text { Suhu } \\
\left({ }^{\circ} \mathrm{C}\right)\end{array}$} & \multirow[b]{2}{*}{ Posisi } & \multirow{2}{*}{$\begin{array}{c}\text { Lama } \\
\text { Pengeringan } \\
\text { (Menit) }\end{array}$} & \multicolumn{2}{|l|}{ Model Lewis } & \multicolumn{2}{|l|}{ Model Page } \\
\hline & & & & $\begin{array}{l}\text { Persamaan Laju } \\
\text { Pengeringan }\end{array}$ & $r^{2}$ & $\begin{array}{c}\text { Persamaan Laju } \\
\text { Pengeringan }\end{array}$ & $r^{2}$ \\
\hline \multirow[t]{6}{*}{1,29} & 61 & $\mathrm{~V}$ & $0-110$ & $M R=\exp -(0,025 t)$ & 0,88 & $M R=\exp -\left(0,116 t^{0,64 t}\right)$ & 0,99 \\
\hline & & $\mathrm{H}$ & $0-110$ & $M R=\exp -(0,026 t)$ & 0,86 & $M R=\exp -\left(0,151 t^{v, \text { ovo }}\right)$ & 0,99 \\
\hline & 52 & V & $0-310$ & $M R=\exp -(0,012 t)$ & 0,48 & $M R=\exp -\left(0,115 t^{0,014}\right)$ & 0,97 \\
\hline & & $\mathrm{H}$ & $0-160$ & $M R=\exp -(0,023 t)$ & 0,88 & $M R=\exp -\left(0,118 \mathrm{t}^{0,652}\right)$ & 0,99 \\
\hline & 41 & V & $0-230$ & $M R=\exp -(0,015 t)$ & 0,78 & $M R=\exp -\left(0,100 t^{0,643}\right)$ & 0,99 \\
\hline & & $\mathrm{H}$ & $0-130$ & $M R=\exp -(0,021 t)$ & 0,92 & $M R=\exp -\left(0,090 t^{0,683}\right)$ & 0,99 \\
\hline \multirow[t]{6}{*}{0,9} & 73 & V & $0-60$ & $M R=\exp -(0,038 t)$ & 0,89 & $M R=\exp -\left(0,155 t^{0,635}\right)$ & 0,99 \\
\hline & & $\mathrm{H}$ & $0-60$ & $M R=\exp -(0,039 t)$ & 0,91 & $M R=\exp -\left(0,148 t^{0,655}\right)$ & 0,99 \\
\hline & 58 & V & $0-100$ & $M R=\exp -(0,025 t)$ & 0,89 & $M R=\exp -\left(0,111 t^{4,00 \prime \prime}\right)$ & 0,99 \\
\hline & & $\mathrm{H}$ & $0-100$ & $M R=\exp -(0,032 t)$ & 0,94 & $M R=\exp -\left(0,112 t^{v, / v^{\prime}}\right)$ & 0,99 \\
\hline & 48 & V & $0-150$ & $M R=\exp -(0,019 t)$ & 0,89 & $M R=\exp -\left(0,091 t^{\mathrm{v}, 0 / v}\right)$ & 0,99 \\
\hline & & $\mathrm{H}$ & $0-160$ & $M R=\exp -(0,019 t)$ & 0,85 & $M R=\exp -\left(0,106 t^{0,636}\right)$ & 0,99 \\
\hline \multirow[t]{6}{*}{0,49} & 92 & V & $0-50$ & $M R=\exp -(0,048 t)$ & 0,85 & $M R=\exp -\left(0,233 t^{0,669}\right)$ & 0,98 \\
\hline & & $\mathrm{H}$ & $0-50$ & $M R=\exp -(0,046 t)$ & 0,92 & $M R=\exp -\left(0,159 t^{0,659}\right)$ & 0,99 \\
\hline & 75 & V & $0-50$ & $M R=\exp -(0,044 t)$ & 0,94 & $M R=\exp -\left(0,135 t^{0,693}\right)$ & 0,99 \\
\hline & & $\mathrm{H}$ & $0-80$ & $M R=\exp -(0,033 t)$ & 0,93 & $M R=\exp -\left(0,123 t^{0,6 / y^{\prime}}\right)$ & 0,99 \\
\hline & 55 & V & $0-140$ & $M R=\exp -(0,022 t)$ & 0,86 & $M R=\exp -\left(0,114 t^{\mathrm{v}, 648}\right)$ & 0,99 \\
\hline & & $\mathrm{H}$ & $0-110$ & $M R=\exp -(0,027 t)$ & 0,94 & $M R=\exp -\left(0,091 t^{v, /<0}\right)$ & 0,99 \\
\hline
\end{tabular}

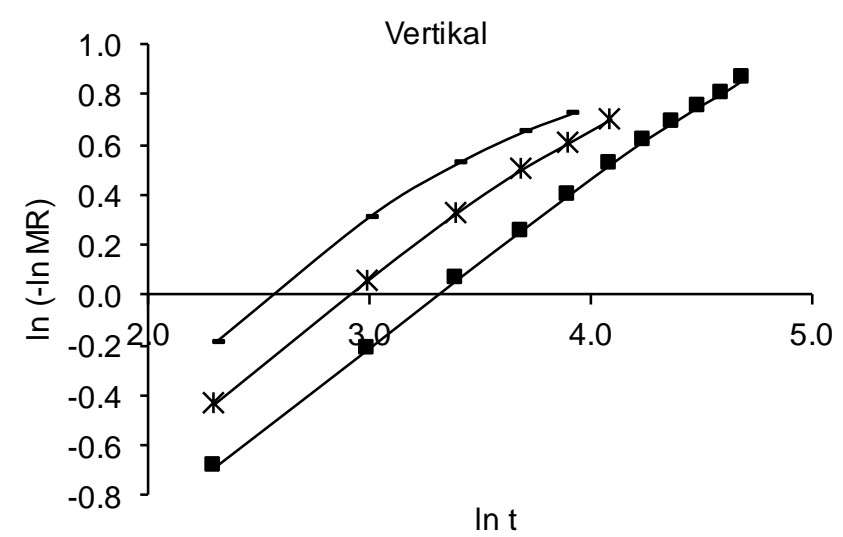

$-\mathrm{V} 1,29 \mathrm{~T} 61 \rightarrow \mathrm{V} 0,90 \mathrm{~T} 73-\mathrm{V} 0,49 \mathrm{~T} 92$

Gambar 3. Kurva persamaan laju pengeringan pada posisi vertikal untuk pengaturan suhu yang sama dengan berbagai kecepatan udara pengering

Kondisi posisi pengeringan terhadap aliran udara pengering memperlihatkan pengaruh yang berbeda terhadap laju pengeringan spageti jagung pada setiap seri kecepatan udara. Pada kecepatan udara $0,90 \mathrm{~m} / \mathrm{s}$, posisi pengeringan tidak terlalu besar pengaruhnya terhadap laju pengeringan spageti jagung. Sementara pada kecepatan udara $1,29 \mathrm{~m} / \mathrm{s}$ dan $0,49 \mathrm{~m} / \mathrm{s}$, posisi pengeringan yang berbeda menunjukkan laju pengeringan yang berbeda pula (Gambar 5). Laju pengeringan posisi vertikal pada kecepatan udara $0,49 \mathrm{~m} / \mathrm{s}$ lebih tinggi dibandingkan posisi horizontal. Sebaliknya, pada kecepatan udara $1,29 \mathrm{~m} / \mathrm{s}$, laju pengeringan pada posisi horizontal lebih tinggi daripada posisi vertikal.

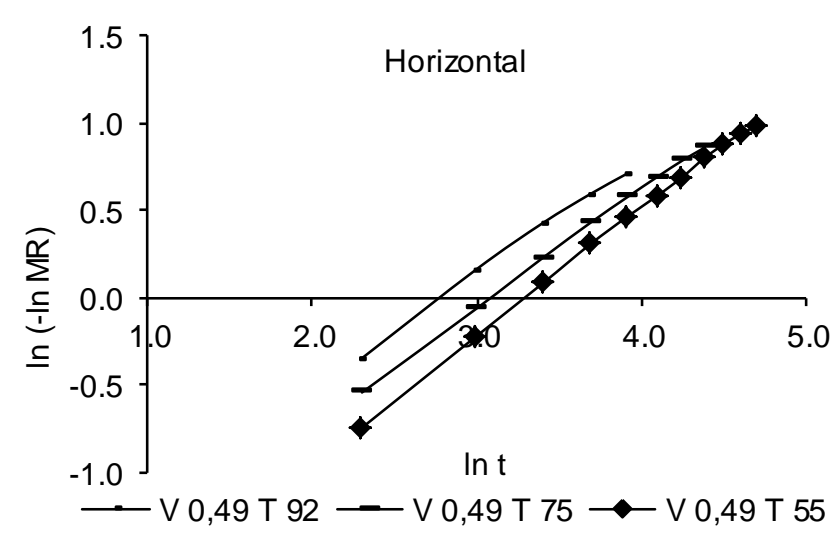

Gambar 4. Kurva persamaan laju pengeringan pada posisi horizontal untuk kecepatan udara yang sama dengan pengaturan suhu berbeda

Posisi pengeringan vertikal memungkinkan seluruh permukaan bahan untuk terekspos udara pengering dalam waktu bersamaan sehingga laju pengeringan dapat menjadi lebih cepat. Penguapan yang cepat di permukaan bahan dapat menyebabkan pembentukan lapisan keras permukaan yang menghambat pemindahan uap air dari dalam bahan sehingga mengurangi laju pengeringan (Thao dan Noomhorm, 2011). Pada kecepatan udara $0,49 \mathrm{~m} / \mathrm{s}$, yang memiliki suhu aktual pengeringan paling tinggi, laju pengeringan terjadi sangat cepat sehingga 
kadar air akhir tercapai sebelum fenomena case hardening menghambat penurunan kadar air. Sedangkan pada kecepatan udara $1,29 \mathrm{~m} / \mathrm{s}$ yang memiliki suhu aktual pengeringan lebih rendah, fenomena case hardening membatasi penurunan kadar air sebelum kadar air akhir 10\% tercapai sehingga laju pengeringan pada posisi vertikal akhirnya menjadi lebih lambat.

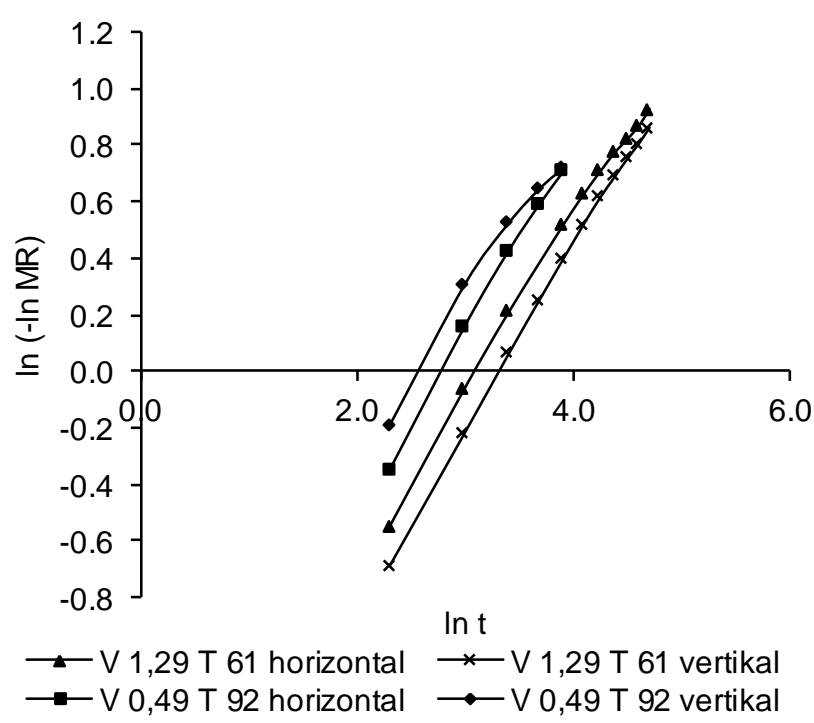

Gambar 5. Kurva persamaan laju pengeringan pada posisi horizontal dan vertikal untuk pengaturan suhu dan kecepatan udara yang sama

\section{KESIMPULAN}

Pengeringan spaghetti jagung dengan aplikasi suhu tinggi efektif mengurangi waktu pengeringan secara signifikan dibanding dengan pengeringan konvensional. Waktu pengeringan spaghetti jagung berkisar antara 50 hingga 310 menit. Laju pengeringan spaghetti jagung dipengaruhi oleh suhu udara pengering. Sementara kecepatan udara pengering tidak memiliki pengaruh langsung terhadap laju pengeringan, tetapi mempengaruhi suhu di ruang pengering. Posisi pengeringan terhadap laju pengeringan juga tidak menunjukkan pengaruh yang besar. Proses pengeringan spaghetti jagung berada pada periode laju pengeringan menurun dan tidak menunjukkan adanya periode laju pengeringan konstan.
Laju pengeringan spaghetti jagung dapat direpresentasikan dengan baik dengan persamaan lapis tipis Page. Koefisien korelasi $\left(r^{2}\right)$ dari persamaan laju pengeringan yang menggunakan model Page menunjukkan nilai korelasi yang sangat baik $(>0,99)$.

\section{DAFTAR PUSTAKA}

[BSN] Badan Standarisasi Nasional. 1992. Biji-bijian, Gaplek dan Bahan lain Sejenis, Penentuan Kadar Air. Jakarta (ID): SNI 01-3182-1992.

[FDA] Food and Drug Administration. 2013. CFRcode of federal regulation title 21 . http:// www.accessdata.fda.gov/scripts/cdrh/cfdocs/cfc fr/CFRSearch.cfm?fr=139.110. [16 Mei 2014].

Erbay Z, Icier F. 2010. A review of thin layer drying of foods: theory, modeling, and experimental results. Crit Rev Food Sci Nutr 50: 441-464. DOI: $10.1080 / 10408390802437063$.

Jayas DS, Cenkowski S, Pabis S, Muir WE. 1991. Review of thin-layer drying and wetting equations. Dry Technol 9: 551-588. DOI: 10.1080/07373939108916697.

Kaushal P, Sharma HK. 2013. Convective dehydration kinetics of noodles prepared from taro (Colocasia esculenta), rice (Oryza sativa) and pigeonpea (Cajanus cajan) flours. Agric Eng Int: CIGR J 15: 202-212.

Kongkiattisak P, Songsermpong S. 2012. Effect of temperature and velocity of drying air on kinetics, quality, and energy consumption in drying process of rice noodles. Kasetsart $\mathrm{J}$ Nat Sci 46: 603-619.

Migliori M, Gabriele D, de Cindio B, Pollini CM. 2005. Modelling of high quality pasta drying: quality indices and industrial application. J Food Eng 71: 242-251. DOI: 10.1016/j.jfoodeng. 2004.11.004.

Pamungkas WH, Bintoro N, Rahayu S, Rahardjo B. 2008. Perubahan Konstanta Laju Pengeringan Pasta dengan Perlakuan Awal Puffing Udara. Di dalam Prosiding Seminar Nasional Teknik Pertanian. 18-19 November 2008, Yogyakarta, Indonesia. 1-15. Yogyakarta (ID): Fakultas Teknologi Pertanian UGM.

Rahayoe S, Rahardjo B, Kusumandari SR. 2008. Konstanta laju pengeringan daun sambiloto menggunakan pengering tekanan rendah. J Rekayasa Proses 2: 17-23. 
Simal S, Femenia A, Garau MC, Rosello C. 2005. Use of exponential, page's and diffusional models to simulate the drying kinetics of kiwi fruit. J Food Eng 66: 323-328. DOI: 10.1016/j. jfoodeng.2004.03.025.

Subarna, Muhandri T, Nurtama B, Firlieyanti AS. 2012. Peningkatan mutu mi kering jagung dengan penerapan kondisi optimum proses dan penambahan monogliserida. J Teknol Industri Pangan 23: 146-152. DOI: 10.6066/jtip.2012. 23.2.146.
Subarna, Muhandri T. 2013. Pembuatan mi jagung kering dengan metode kalendering. J Teknol Industri Pangan 24: 75-80. DOI: 10.6066/jtip. 2013.24.1.75.

Thao HM, Noomhorm A. 2011. Modelling and effects of various drying methods on sweet potato starch properties. Walailak J Sci Technol 8: 139-158.

Villeneuve S, Géllinas P. 2007. Drying kinetics of whole durum wheat pasta according to temperature and relative humidity. LWT-Food Sci Technol 40: 465-471. DOI: 10.1016/j.lwt. 2006.01.004. 